\title{
DEEP WELL AS A FACILITY FOR ON-LINE HYDRAULIC STUDIES OF THE STRESS STATE OF THE ROCK MASS IN FLUID-SATURATED FRACTURED RESERVOIRS
}

\author{
A. G. Vakhromeev 1, 2, 3, V. M. Ivanishin², S. A. Sverkunov1, 2, 3, 4, \\ V. N. Polyakov ${ }^{5}$, R. K. Razyapov 6 \\ ${ }^{1}$ Institute of the Earth's Crust, Siberian Branch of RAS, Irkutsk, Russia \\ ${ }^{2}$ Irkutsk Branch of LLC RN-Burenie, Irkutsk, Russia \\ ${ }^{3}$ Irkutsk National Research Technical University, Irkutsk, Russia \\ ${ }^{4}$ Irkutsk Scientific Center, Siberian Branch of RAS, Irkutsk, Russia \\ ${ }^{5}$ Institute of Oil and Gas Technologies and New Materials of the Republic of Bashkortostan, Ufa, Russia \\ ${ }^{6}$ LLC Sorovskneft, Tyumen, Russia
}

\begin{abstract}
In the southern areas of the Siberian platform, geological and mining conditions are highly complex for design, drilling and construction of deep wells for oil and gas. Complicating factors are related to specific features of deforming cavity-fractured carbonate reservoirs. Geological models of carbonate reservoirs should be designed on a case-by-case basis, taking into consideration the conditions of each specific field, including its complex filtration field, confirmed deformation of filtering fractures with constant parameters of the cavern component, etc. If an incomprehensive geological model is used for production planning with a lack of a well-based approach to the development of a carbonate reservoir, design well flow rates may not be achieved, the field reserve coverage will be reduced and, consequently, the oil recovery ratio will be lower. When developing oil, gas and brine deposits, it is required to consider the natural-technical system of 'reservoir - reservoir' (mechanical impact) - 'reservoir fluid system and well' (hydrodynamic impact) on the basis of a comprehensive analysis of its interrelated and interdependent components. Our study shows that each part of the system contributes directly to the entire complex. The stress state of the rock mass in the fluid-permeable part of the natural fractured reservoir and fluid-saturated reservoirs is dynamically changeable during the fluctuations of the pressure field of the reservoir hydrocarbon system at the initial penetration of a well into the reservoir. The authors analyzed the natural-technical system 'well - fluid-saturated bed' as a real on-line model of leaking - hydraulic fracturing based on a standard pressure vs. time curve during hydraulic fracturing. Based on the knowledge of the on-going processes in carbonate cavern-fractured reservoirs, it becomes possible to predict the reaction of the rock mass during hydraulic repression (i.e., during the initial penetration of a well into the reservoir) and depression (during testing and operations of a production well). All pressure effects hydraulically applied to the reservoir fluid system can lead to changes in the stress state of the natural reservoir. The stress state with significantly changing permeability parameters of filtering fractures is among the most complex states of stress [Belonin et al., 2005; Borevsky, 1986]. It is important to take into account that such stress state transition during the drilling
\end{abstract}

For citation: Vakhromeev A.G., Ivanishin V.M., Sverkunov S.A., Polyakov V.N., Razyapov R.K., 2019. Deep well as a facility for on-line hydraulic studies of the stress state of the rock mass in fluid-saturated fractured reservoirs. Geodynamics \& Tectonophysics 10 (3), $761-778$. doi:10.5800/GT-2019-10-3-0440. 
process is uncontrollable and unpredictable, which means that the reservoir permeability and porosity may be irreversibly affected and considerably reduced and, consequently, the oil well productivity and the final profitability of developing the hydrocarbon field will be significantly decreased. Based on the actual deep drilling data, we continue comprehensive studies of deforming fractured reservoirs in the area of the stress state of the rock mass and investigation of pressure characteristics of fluid systems and their mutual influence during hydraulic operations in the well completion cycle. We have analyzed the stress state of the rock mass in various reservoirs. Indicators characterizing a particular state of the rock mass are substantiated. Geological and technological recommendations are specified for the initial penetration of wells into the reservoir, as well as for testing the wells with respect to the state of the natural-technical system 'well - fluid-saturated formation'. New geological and technological solutions are proposed.

Key words: stress state; geodynamics; drilling; horizontal well section; drill-in technology of initial penetration; Riphean carbonate fractured reservoir

\title{
ГЛУБОКАЯ СКВАЖИНА КАК СТЕНД ГИДРАВЛИЧЕСКИХ «ОN-LINE» ИССЛЕДОВАНИЙ НАПРЯЖЕННОГО СОСТОЯНИЯ ГОРНОГО МАССИВА ФЛЮИДОНАСЫЩЕННЫХ ТРЕЩИННЫХ КОЛЛЕКТОРОВ
}

\author{
А. Г. Вахромеев ${ }^{1,2,3}$, В. М. Иванишин ${ }^{2}$, С. А. Сверкунов ${ }^{1,2,3,4}$, \\ В. Н. Поляков ${ }^{5}$, Р. К. Разяпов 6 \\ ${ }^{1}$ Институт земной коры СО РАН, Иркутск, Россия \\ ${ }^{2}$ Иркутский филиал ООО «РН-Бурение», Иркутск, Россия \\ ${ }^{3}$ Иркутский национальный исследовательский технический университет, Иркутск, Россия \\ ${ }^{4}$ Иркутский научный центр СО РАН, Иркутск, Россия \\ ${ }^{5}$ Институт нефтегазовых технологий и новых материалов Республики Башкортостан, \\ Уфа, Россия \\ ${ }^{6}$ ООО «Соровскнефть», Тюмень, Россия
}

\begin{abstract}
Аннотация: Горно-геологические условия бурения глубоких скважин на нефть и газ на территории юга Сибирской платформы отличаются высокой сложностью проектирования и строительства. Осложняющим фактором являются специфические особенности сложных деформируемых каверново-трещинных карбонатных коллекторов. Проектирование геологической модели карбонатного коллектора должно выполняться индивидуально, с учетом условий каждого конкретного месторождения, в том числе сложного фильтрационного поля, доказанного явления деформации фильтрующих трещин при неизменных параметрах каверновой составляющей и т.д. Неполная геологическая модель и отсутствие подхода к разработке карбонатных продуктивных пластов могут явиться причиной недостижения проектных значений дебитов скважин, снижения охвата запасов месторождения и, соответственно, уменьшения коэффициента извлечения нефти. При разработке месторождений нефти, газа или промышленных рассолов необходимо рассматривать природно-техническую систему «пласт - коллектор» (механическое воздействие) - «пластовая флюидная система» и «скважина» (гидродинамическое воздействие) на основе комплексного анализа ее неразрывных составных частей. В данном исследовании показано, что каждая часть системы вносит непосредственный вклад в общий комплекс. Напряженное состояние горного массива породы-коллектора проницаемой части природного трещинного резервуара, флюидонасыщенных пластов-коллекторов может динамически меняться в процессе колебаний барического поля пластовой углеводородной системы в первичном вскрытии пласта. Авторами проведен анализ природно-технической системы «скважина - флюидонасыщенный пласт» как реальной «on-line»модели процесса «утечки» - ГРП на основе стандартного графика зависимости давления от времени при гидроразрыве пласта. Исследование процессов, происходящих в текущий момент бурения в карбонатных каверно-трещинных коллекторах, позволяет делать прогноз на реакцию горного массива пород при гидравлическом приложении к нему репрессии (т.е. при первичном вскрытии коллектора во время бурения скважин) и депрессии (при проведении работ по испытанию и освоению продуктивной скважины). Все барические воздействия, гидравлически приложенные к пластовой флюидной системе, способны перевести природный резервуар в другое напряженное состояние. Одно из наиболее сложных - состояние с существенно меняющимися параметрами проницаемости фильтрующих трещин [Belonin et al., 2005; Borevsky, 1986]. Важно понимать, что если этот переход в процессе бурения является неконтролируемым и непрогнозируемым, на практике можно необратимо существенно снизить фильтрационно-емкостные свойства коллектора, а значит - потерять продуктивность скважин по нефти и конечные показатели рентабельности освоения месторождения углеводородов. По фактурным данным глубокого бурения авторами продолжены комплексные исследования деформируемых трещинных коллекторов в области напряженного состояния массива и барических характеристик флюидных систем, их взаимного влияния при гидравлическом воздействии в цикле заканчивания
\end{abstract}


скважин, проанализированы различные напряженные состояния горного массива коллекторов. Обоснованы индикаторы, характеризующие то или иное состояние горного массива. Выданы геолого-технологические рекомендации по первичному вскрытию продуктивного пласта, а также по проведению испытаний скважины в зависимости от состояния природно-технической системы «скважина - флюидонасыщенный пласт». Разработаны новые геолого-технологические решения.

Ключевые слова: напряженное состояние; геодинамика; бурение; горизонтальный ствол; технология первичного вскрытия; карбонатный трещинный резервуар рифея

\section{1. ВВЕДЕНИЕ}

Условия строительства глубоких нефтяных и газовых скважин на территории юга Сибирской платформы характеризуются высокой сложностью [Ovnatanov, 1979; Zalivin, Vakhromeev, 2016]. Специфические особенности состояния каверно-трещинных карбонатных коллекторов являются осложняющим фактором. Деформация, то есть изменение проницаемости, расширение либо смыкание фильтрующих трещин в призабойной зоне пласта при гидравлическом воздействии/создании репрессии или депрессии, ранее прогнозируемое [Ovnatanov, 1979] и доказанное [Belonin et al., 2005; Borevsky, 1986, Kashnikov et al., 2011; Vakhromeev et al., 2015], на ряде месторождений углеводородов (УВ) в природном резервуаре (ПР) нефти и газа является одной из основных скрытых проблем, возникающих при бурении скважин, их испытании и последующем освоении (добыче) пластовых систем [van GolfRacht, 1982; Pinneker, 1977; Zalivin, Vakhromeev, 2016; Polyakov et al., 1999]. К таким системам «природный резервуар - флюидная система» относят флюидонасыщенные (от непереливающих до фонтанирующих нефтью и газом, промышленными или минеральными водами с разными барическими условиями вплоть до аномально высокого пластового давления (АВПД)) пласты-коллекторы со сложным трещинным типом проницаемости. Это явление изменения проницаемости обуславливает как постепенное или резкое поглощение при репрессии [Polyakov et al., 1999; Siraev et al., 2013], так и снижение дебита пластовой жидкости скважины при депрессии [Belonin et al., 2005; Kashnikov et al., 2011]. Очевидно, существующую проблему необходимо рассматривать в комплексе природно-технической системы «скважина - пласт». Под пластовой флюидной, флюидодинамической системой при этом подразумевается природный резервуар нефти и газа, промышленных вод, вмещающий флюидную, точнее флюидонапорную, систему залежи [Pinneker, 1977; Zalivin, Vakhromeev, 2016; Vakhromeev et al., 2017].

\section{2. МЕТОДЫ ПРОВЕДЕНИЯ ИССЛЕДОВАНИЯ И ОСНОВНЫЕ ПОЛОЖЕНИЯ ТЕОРИИ НАПРЯЖЕННОГО СОСТОЯНИЯ гОРНЫХ ПОРОД}

Геологическая среда априори находится в напряженном состоянии. Анализ опубликованных работ по исследованиям напряженного состояния массива горных пород в земной коре и, в частности, массива пород-коллекторов, вмещающих и фильтрующих флюиды (нефть, газ, подземные воды) [Belonin et al., 2005; Borevsky, 1986; Kashnikov et al., 2011; Vakhromeev et al., 2015], показывает, что решается довольно широкий круг задач. Бурение и освоение глубоких скважин на нефть и газ дополнительно осложняют и без того сложное поле напряжений флюидонасыщенного массива горных пород. Выявление и исследование закономерностей развития обратимых и необратимых изменений, деформаций фильтрующих трещин в призабойной зоне пласта скважин и в продуктивном пласте с УВ или гидроминеральным насыщением как в лабораторном эксперименте [Kashnikov et al., 2011], так и на скважине в цикле заканчивания [Polyakov et al., 1999] крайне необходимы для решения вопросов:

- корректной оценки гидродинамических параметров продуктивного пласта-коллектора, таких как проницаемость, продуктивность по нефти, газоконденсатной смеси;

- корректной оценки извлекаемых запасов УВсистемы;

- обоснования допустимого диапазона депрессии на систему пласт - залежь (флюидодинамическая система);

- проектирования гидроразрыва пласта (ГРП) во всех его модификациях.

Рассматриваемое направление исследований имеет научно-практический аспект, разработка которого требует «настройки» цикла заканчивания скважины на горно-геологические и геомеханические условия конкретного природного резервуара, с учетом свойств пластовых углеводородных систем либо промышленных вод и, 
на наш взгляд, нуждается в дальнейшей проработке.

Обоснование технологических подходов к бурению, испытанию на продуктивность (ГДИ) и освоению слоистых и массивных трещинных резервуаров гетерофазных сред - нефти, газа и металлоносных рассолов, представленных деформируемыми коллекторами, рассмотрено в работах [Dobrynin, 1970; Belonin et al., 2005; Borevsky, 1986; Karev, 2010; Kashnikov et al., 2011; Nazarova et al., 2013; Doroginitskaya et al., 2016; Vakhromeev et al., 2015, 2017, 2018]. Так, в работах [Karev, 2010] проведено изучение влияния реально возникающих в окрестности горизонтальной скважины напряжений на фильтрационные и прочностные свойства горных пород морского месторождения «Приразломное». Исследовались породы из двух интервалов продуктивного разреза с различными структурно-литологическими характеристиками. Эксперименты проводились на испытательной системе трехосного независимого нагружения Института проблем механики РАН. Моделирование показало, что фильтрационные свойства исследуемых пород сильно зависят от напряженно-деформированного состояния. При понижении давления в скважине до определенного критического значения они ухудшаются. К этому же выводу приходят [Borevsky, 1986; Belonin et al., 2005; Kashnikov et al., 2011].

Карбонатный коллектор, в котором развита вторичная трещиноватость, как правило, анизотропен. Свойство анизотропии трещиноватости в целом и фильтрующих трещин в частности предполагает, что открытая система трещин находится в области наименьших напряжений, но и является результатом тектонофизических реакций горного массива пород-коллекторов на внешнее воздействие напряжений [Seminsky, 2003; Migursky, 1997; Migursky et al., 2010]. Одним из гидравлических следствий этого является снижение составляющей горного давления на стенки трещин до значений, равных (или ниже) давлению пластовой флюидной системы ( $\left.\mathrm{P}_{\text {пл}}\right)$ [Kontorovich, 2004; Vakhromeev et al., 2015, 2017], распределенной в пустотном пространстве ПР.

Залежи УВ либо рассолов локализованы в «ловушках» - замкнутых объемах пустотного пространства ПР, и любые изменения объема пустотного пространства $\left(\mathrm{V}_{\Pi \mathrm{P}}\right)$ прямо ведут к реакции $\mathrm{PV} / \mathrm{T}$ (давление, объем, температура) параметров системы. Как следствие, - инициация природного процесса ГРП, импульсное возникновение которого [Migursky, 1997] приводит к сбросу $\mathrm{P}_{\text {пл }}$ флюидной системы в замкнутом объеме резервуара. Одним из ярких примеров этого процесса было внедрение в осадочный чехол щелочной магмы и масштабное формирование трапповых силлов на Сибирской платформе.
Из этих тезисов следует, что формирование анизотропной системы трещиноватости в проницаемом массиве горных пород - природном резервуаре - может идти как под геомеханическим, так и под гидравлическим воздействием, причем оба механизма формируют область/зону разуплотнения и фильтрационное поле трещинных природных резервуаров [Seminsky, 2003; Migursky, 1997; Vakhromeev et al., 2015]. По К.Ж. Семинскому, под зоной разуплотнения как объемным деформационным элементом понимают «...совокупность структурных элементов, определяющих специфику ее строения в отличие от окружающих (ненарушенных) пространств и имеющих существенно большие по размерам горных пород объемы, чем тектонический сместитель, в которых имеют место разрывные и пластические деформации» [Seminsky, 2003].

Другими словами, механизм гидравлического воздействия на проницаемую, т.е. фильтрующую флюиды (нефть, газ, рассолы), систему трещин, природную фильтрационную среду трещинного резервуара не только имеет место как один из процессов трещино- и разломообразования [Seminsky, 2003; Seminsky et al., 2013], он должен рассматриваться в одном ряду факторов формирования длины природной трещины в ПР [Vakhromeev et al., 2014, 2015, 2017, 2018]. Проведем параллель: именно этот процесс технически оформлен сегодня в мощные аппаратурно-технологические комплексы реализации ГРП для создания систем искусственных трещин на месторождениях с низкими фильтрационно-емкостными свойствами (ФЕС) нефтенасыщенных ПР практически на всех континентах нашей планеты [Usachev, 1986].

Однако процесс гидравлического воздействия на массив горных пород происходит непрерывно с момента первичного вскрытия бурением поровых либо трещиноватых пород коллекторов через гидравлическое воздействие циркулирующего под давлением бурового раствора [Polyakov et al., 1999]. Рассматривая систему «флюидонасыщенный трещинный коллектор $\rightarrow$ скважина в бурении» (при циркуляции промывочной жидкости и без нее), мы, по сути, рассматриваем активный гидравлический механизм «on-line»-воздействия через скважину на трещинный ПР в диапазоне реальных давлений жидкости от притока, т.е. от депрессии и газонефтеводопроявления (ГНВП) $\left(\downarrow \mathrm{P}_{\text {жидк в скв }}\right.$ (давление

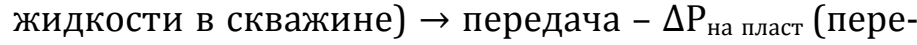
пад давления)) до репрессии и гидравлического разрыва пласта, ГРП (१Р жидк в скв. $\rightarrow$ передача +

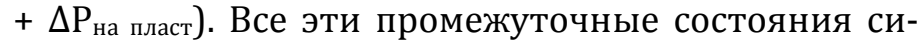
стемы «циркуляционная система скважины - флюидонасыщенный пласт» от проявления флюидов из продуктивного пласта до ГРП и поглощения буро- 
вого раствора на практике реализуются через гетерогенную флюидную систему (жидкость), где в скважине - буровой раствор, в пласте - жидкий флюид (нефть, рапа и растворенный газ) в одной или двух фазах (жидкость/свободный газ).

В таком подходе система скважина - флюидонасыщенный пласт является реальной моделью природного процесса и одновременно - экспериментальным «стендом» процесса природного ГРП флюидов в земной коре или ГРП расплава магмы [Migursky, 1997]. Это реальный «on-line»-стенд гидравлических воздействий. По сути, изучение гидравлического воздействия ГРП как геологического процесса позволяет исследовать регулируемое воздействие промывочной жидкостью - буровым раствором (БР) - на трещинное пространство ПР через флюидную систему в пласте-коллекторе, «каркас» которого находится в геомеханически напряженном состоянии. Ведь в фильтрационном поле продуктивного пласта резервуара также распределена жидкость - нефть, рассолы - рапа [Borevsky, 1986; Vakhromeev et al., 2015]. Более того, рассматриваемые нами необычайно широкие по спектру исследования ГРП-процесса во всех его вариациях имеют конечной целью решение практических задач в освоении трещинных ПР с незначительными, низкими или мозаично меняющимися параметрами проницаемости нефтенасыщенного ПР [Vakhromeev et al., 2015, 2017].

Исследования искусственного (технического) гидравлического воздействия ГРП-процесса и практический опыт в подавляющей своей массе (экспериментов, опытов, фактов, публикаций) базируются на рассмотрении процесса формирования искусственной трещины или системы трещин [Usachev, 1986]. Принципы эти сегодня реализуются преимущественно в поровых или трещинно-поровых ПР. Подчеркнем, что в реальной практике за рамками исследований ГРП-тематики остается очень важная по своему смыслу область исследований это «деформируемые» трещинные коллекторы, т.е. коллекторы с изменяющейся по величине проницаемостью [Belonin et al., 2005; Borevsky, 1986; Vakhromeev et al., 2014, 2015, 2017]. Проблематика исследований деформируемых коллекторов в циклах геологоразведочного бурения и добычи нефти эксплуатационными скважинами, в т.ч. с горизонтальным окончанием, менее изучена [Borevsky, 1986; Kashnikov et al., 2011].

Основной и в ряде научных работ единственной рабочей, практической рекомендацией авторов [Belonin et al., 2005; Kashnikov et al., 2011] является ограничение депрессии на нефтяной пласт тем диапазоном перепада давлений $(\Delta \mathrm{P})$, который экспериментально установлен в цикле геологоразведочных работ (ГРР).
Что же получается? С одной стороны, технология ГРП не просто развивается на просторах России, она входит в пул инновационных подходов, ведь эффективность создания и закрепления искусственных трещин общепризнана [Usachev, 1986; Belonin et al., 2005; Kashnikov et al., 2011]. В то же время деформируемые трещинные коллекторы природные проницаемые трещинные системы - в целом остаются отдельной и «нерешаемой» областью в ГРР и освоении месторождений и залежей нефти и газа, промышленных литиеносных рассолов бурением, в т.ч. горизонтальным [Vakhromeev et al., 2014, 2015, 2017].

Отечественный опыт бурения, геопромысловых исследований и освоения залежей УВ в трещинных коллекторах приводит авторов к твердому убеждению, что эта проблема - проблема деформируемых коллекторов - решается рационально и эффективно. Разрабатывая варианты технологических подходов к бурению горизонтальных стволов (ГС) большой протяженности в трещинных коллекторах рифея, на I этапе авторы пришли к серии базовых выводов:

- о том, что проницаемость трещинных коллекторов анизотропна и переменна, а каверновых постоянна [Kontorovich et al., 1988; Vakhromeev et al., 2015, 2017; Kharakhinov, Shlenkin, 2011];

- о том, что для ряда изученных бурением проницаемых трещинных резервуаров горизонтальная составляющая горного давления на стенки проницаемых трещин $\leq \mathrm{P}_{\text {пл }}$ флюидной системы, а сам механизм формирования раскрытой, т.е. фильтрующей, трещины в определенном объеме исследован [Usachev, 1986; Migursky, 1997; Vakhromeev Shlenkin 2015, 2017];

- о том, что аномально низкое пластовое давление (АНПД) пластовой УВ-системы дополнительно осложняет бурение ГС [Sverkunov et al., 2016b];

- о том, что поглощающие зоны трещиноватости/кавернозности реагируют на кольматацию поразному: каверны с постоянным неизменяющимся объемом пустотного пространства закольматировать не удается, а трещинные системы, как правило, кольматируются. Однако проводимая опрессовка открытого ствола с кольматационным экраном приводит к открытию нового/повторного поглощения [Sverkunov et al., 2016b], что связано с определенным (1-2 МПа) плановым повышением забойного давления в скважине в процессе «Leak of test» (тест на определение значения давления начала поглощения/утечки). Это явление трактуется нами [Vakhromeev et al., 2017; Sverkunov et al., 2016b] как повышение проницаемости фильтрующей трещины во время гидравлически создаваемого буровым раствором дополнительного давления (репрессии + $\Delta \mathrm{P}$ и «проскок», перемещение в эту трещину и 
систему трещин кольматанта, размер частиц которого фиксирован).

Отдельно следует обозначить именно гидравлические следствия «on-line»-воздействия бурового раствора на трещинную и флюидную системы при бурении ГС:

- это колебательное воздействие жидкости (бурового раствора, нефти), которое генерируется буровыми насосами [Polyakov et al., 1999];

- это явление одновременного поглощения на забое ГС и нефтегазопроявления в начале горизонтального ствола скважины, которое обусловлено перепадом динамической составляющей давления жидкости БР по длине ГС [Sverkunov et al., 2016b];

- это падение давления поглощения (при вскрытии забоем скважины поглощающих трещин, на репрессии) до величины Рпл - пластового давления флюидной системы, например пластовой нефти, распределенной в пустотном пространстве трещинного резервуара [Sverkunov et al., 2016b; Zalivin, Vakhromeev, 2016].

\section{3. РЕЗУЛЬТАТЫ ИССЛЕДОВАНИЙ НАПРЯЖЕННОГО СОСТОЯНИЯ ГОРНОГО МАССИВА ПОРОД- КОЛЛЕКТОРОВ}

Напряженное состояние горного массива проницаемой части природного трещинного резервуара, флюидонасыщенных пластов-коллекторов заслуживает отдельного внимания, как часть рассматриваемой нами общей природно-технической системы. Попробуем проанализировать природнотехническую систему «скважина - флюидонасыщенный пласт» как реальную «on-line»-модель процесса «утечки» (ГРП) на основе стандартного графика зависимости давления от времени при гидроразрыве пласта (рис. 1).

В данном случае речь идет о проницаемом для флюидов пласте или о фильтрационной системе трещинного резервуара. По графику видно, что существует как минимум три состояния (зоны 1-3) напряжений горного массива.

Состояние (зона) 1 характеризует горный массив, представленный трещиноватым коллектором, в котором существует естественная сеть трещин просветом не более десятых мДарси. При гидравлическом повышении давления в скважине забойное давление сначала растет пропорционально времени (линейный участок на графике). Далее существует переходная зона, в которой давление начинает расти медленнее (давление начала поглощения или «утечки» и расширение искусственной трещины). Затем происходит гидроразрыв, резкое снижение давления. Далее мы видим стабилизацию давления на определенном уровне, что соответствует значению приемистости пласта. При снижении забойного давления начинается смыкание трещины гидроразрыва, что характеризуется плавным падением давления и стабилизацией его на определенном уровне.

Состояние (зона) 2 характеризует горный массив, представленный трещиноватым коллектором с уже созданной трещиной гидроразрыва. Но трещина гидроразрыва в этой зоне сомкнута. При этом значение давления открытия трещины также будет меньше величины давления гидроразрыва в зоне 1.

Состояние (зона) 3 характеризует горный массив, представленный трещиноватым коллектором с уже созданной трещиной гидроразрыва. При этом трещина гидроразрыва в определенном диапазоне забойного давления может быть постоянно открыта (аномально гидропроводный коллектор).

Рассматривая результаты опытов «leak off test», т.е. флюидную систему совместно с фильтрационной системой трещинного резервуара, авторы приходят к выводу, что каждая из трех зон, показанных на рисунке 1, может быть одним из состояний реального флюидонасыщенного массива природного резервуара в настоящий момент времени. Иными словами, коллектор может быть «стандартным» - поровым, в котором проводится гидроразрыв (зона 1), аномальным по проницаемости с естественными или искусственными закрытыми трещинами искусственного или природного «гидроразрыва» (зона 2), аномальным с естественными или искусственными открытыми трещинами «гидроразрыва». В качестве примера зоны 3 можно привести нефтенасыщенный трещинный резервуap рифея на одном из месторождений юга Сибирской платформы с естественными вертикальными трещинами с просветом до нескольких десятков сантиметров (единицы и нередко десятки Дарси) [Kharakhinov, Shlenkin, 2011; Kharakhinov et al., 2012; Kiselev et al., 2011, 2012; Vakhromeev et al., 2015; Kutukova et al., 2012].

При этом, «накладывая» данные по флюидной системе, можно прогнозировать реакцию трещинного резервуара (поглощение, проявление, смыкание, раскрытие трещин) на снижение или увеличение забойного давления в процессе бурения скважин по заданным коллекторам (рис. 2, 3). Используя исходные барические данные природной флюидной системы резервуара и значения расчетного давления на стенки фильтрующих трещин, можно прогнозировать открытие и смыкание трещин в каждой выделенной зоне.

Из анализа графиков следует вывод, что при снижении забойного/пластового давления до определенного уровня наступает смыкание трещин и снижается проницаемость в области падения 


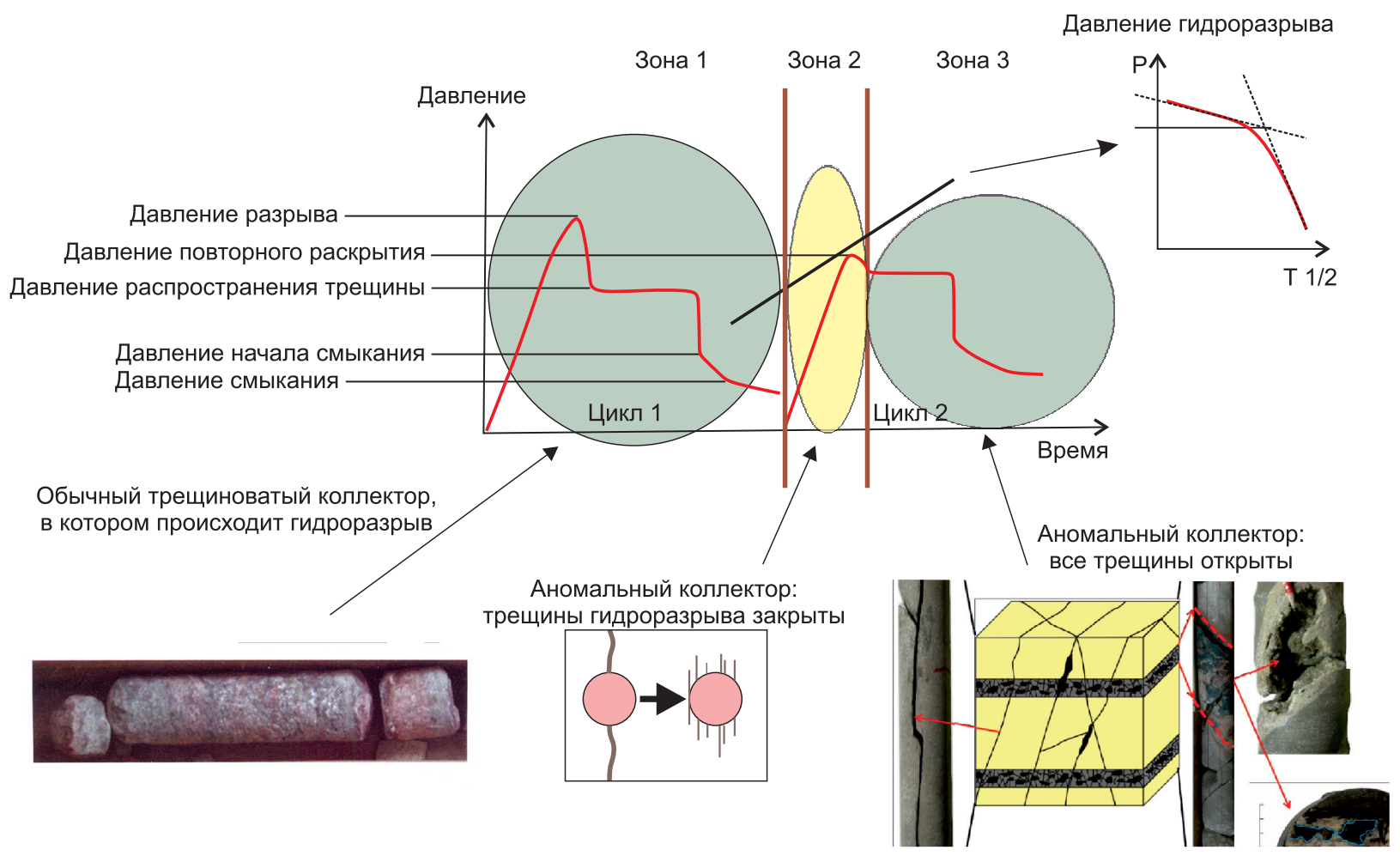

Рис. 1. График первичного гидравлического разрыва горных пород (зона 1) и повторного приоткрывания вновь образованных проницаемых трещин (зона 2, 3) с дополнением.

Fig. 1. Curve of initial hydraulic fracturing of rocks (Zone 1) and reopening of the newly formed permeable cracks (Zones 2 and 3 ), and additional data.

давления [Borevsky, 1986; Kashnikov et al., 2011; Vakhromeev et al., 2015]. При этом, чтобы в дальнейшем снова «раскрыть» эти трещины, недостаточно гидравлически «вернуть» давление на начальные значения, при которых трещины были открыты. Необходимо повысить давление флюидной системы до уровня раскрытия трещины (зона 2), то есть до величины давления утечки.

Подчеркнем, что по результатам геолого-промыслового и технологического сопровождения в цикле первичного вскрытия трещинных ПР одно и то же забойное/пластовое давление флюидной системы в разных напряженных состояниях горного массива может соответствовать совершенно разным состояниям естественных фильтрующих трещин (рис. 4,5$)$. Эта идея обоснована в работе [Doroginitskaya et al., 2016].

В качестве примера рассмотрим пластовую систему нефтенасыщенного трещинного карбонатного резервуара рифея одного из месторождений юга Сибирской платформы. Согласно исследованиям [Kontorovich et al., 1988; Kontorovich, 2004], показано, что все вертикальные трещины открыты [Vakhromeev et al., 2015; Kutukova et al., 2012; Postnikova et al., 2001]. Это напряженное состояние массива соответствует приведенному на рис. 3.
Действительно, согласно уравнению Терцаги вертикальное горное давление $P_{r}$ рассчитывается как:

$$
P_{r}=\frac{1}{3} H \rho g\left(1+\frac{2^{-\sigma}}{1^{-\sigma}}\right),
$$

где $H$ - глубина, $\rho$ - плотность горных пород, $\sigma$ сжимающее напряжение.

Боковое горное давление $P_{\text {бок }}$ соответственно

$$
P_{\text {бок }}=\left(\frac{\sigma}{1-\sigma}\right) P_{r} \text {. }
$$

Давление, создаваемое на стенки наклонной трещины $P_{a}$ :

$$
P_{\mathrm{a}}=\sqrt{\left.P_{\text {бок }} \mathrm{T}+\left(1-\frac{1}{P_{r}^{2}}\right) \frac{P_{r}^{2} P_{\text {бок }}{ }^{2}}{P_{\text {бок }}{ }^{2}+P_{r}{ }^{2} t g^{2} \alpha}\right)},
$$

где $\alpha$ - угол падения трещин.

Таким образом, иллюстрируется вывод о том, что вертикальные трещины имеют бо́льшую раскрытость $b$, чем наклонные, что характеризуется коэффициентом K:

$$
K_{b}=\left(\frac{b_{\text {накл }}}{b_{\text {верт }}}\right)=\frac{P_{\alpha=50}}{P_{\alpha=80}} \rightarrow k \approx \frac{1}{7} .
$$




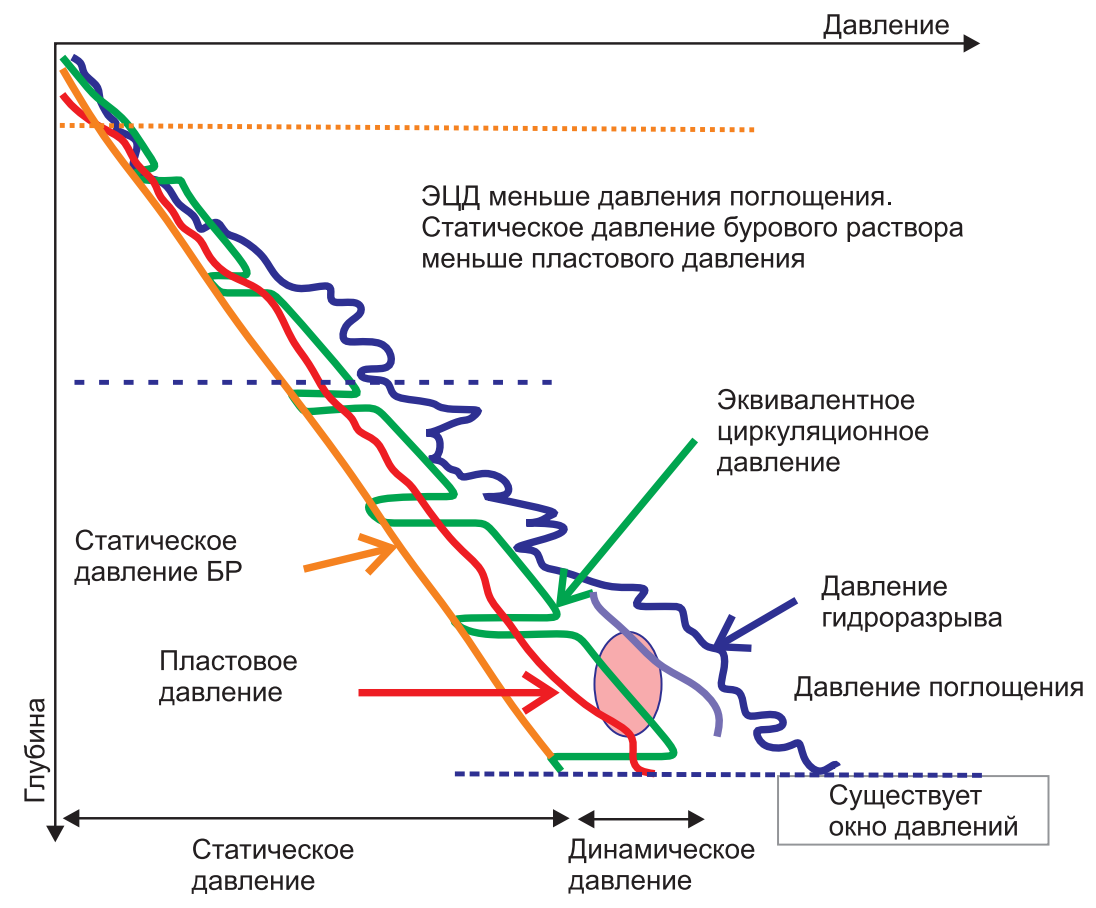

Рис. 2. Совмещенный график горно-геологических условий бурения в координатах глубина/давление (зона 2, аномально проницаемый коллектор, трещины гидроразрыва закрыты) (по версии сервисных подрядчиков с дополнением). Желтая линия показывает величину статического давления бурового раствора (БР); красная - пластовое давление флюидной системы; зеленая - эквивалентное давление циркуляции БР; синяя - давление поглощения.

Fig. 2. Combined graph of the geological and mining conditions for drilling in depth/pressure coordinates (zone 2; anomalously permeable reservoir; hydrofrac cracks are closed) (based on the data provided by the service contractors and additional data). Yellow line - static pressure of the drilling fluid; red line - reservoir pressure of the fluid system; green line equivalent pressure of the drilling fluid circulation; blue line - absorption pressure.

И соответственно величина горного давления на стенки вертикальных трещин будет значительно меньше, чем на стенки наклонных и тем более горизонтальных трещин.

Таким образом, при первичном вскрытии пластаколлектора текущее забойное давление в момент вскрытия забоем скважины зоны вертикальной трещины резко падает до пластового давления, что соотносится со схемой, показанной на рис. 5, a [Sverkunov et al., 2016b]. Выявление данного эффекта защищено патентом РФ [Vakhromeev et al., 2016]. ПР находится в состоянии постоянно открытых трещин, при этом пластовое давление флюидной системы является максимальным по величине давлением, при котором возможна закачка жидкости в пласт. Для процесса бурения скважин такое состояние природно-технической системы является крайне сложным, в нем полностью отсутствует «окно давлений» [Sverkunov et al., 2016b] для бурения скважины (см. рис. 3). Стандартные технологии бурения в данном случае применять небезопасно.

В работах [Polyakov et al., 1999; Vakhromeev et al., 2015, 2017; Sverkunov et al., 2016b] показано, что для первичного вскрытия трещинных коллекторов ра- бочий диапазон текущих забойных давлений в призабойной зоне пласта (ПЗП) не ограничивается областью депрессии, а находится в диапазоне от репрессии до депрессии относительно пластовых давлений флюидной системы. По сути, такой коллектор характеризуется равновесными условиями пластового давления флюида и горизонтальной составляющей горного давления на стенки трещин ПЗП, фильтрующих как буровой раствор в первичном вскрытии в условиях $\mathrm{P}_{\text {тек }}$ (текущее забойное давление) $>\mathrm{P}_{\text {пл}}$, так и флюид из пласта (нефть, газ и т.д.) в условиях $\mathrm{P}_{\text {тек }}<\mathrm{P}_{\text {пл}}$.

Бурение горизонтальных стволов большой протяженности в таких равновесно-неравновесных [Vakhromeev et al., 2015, 2017; Sverkunov et al., 2016b] системах позволило впервые уточнить «оn-line» текущие гидродинамические условия на забое скважины и в области открытого ствола (как вертикального, так и наклонного и горизонтального), при которых эти явления не только имеют место как научный факт [Vakhromeev et al., 2015, 2017; Sverkunov et al., 2016b], но и являются геологотехнологической проблемой безаварийного [Svintsitsky, 2006; Siraev et al., 2013] и планомерного 


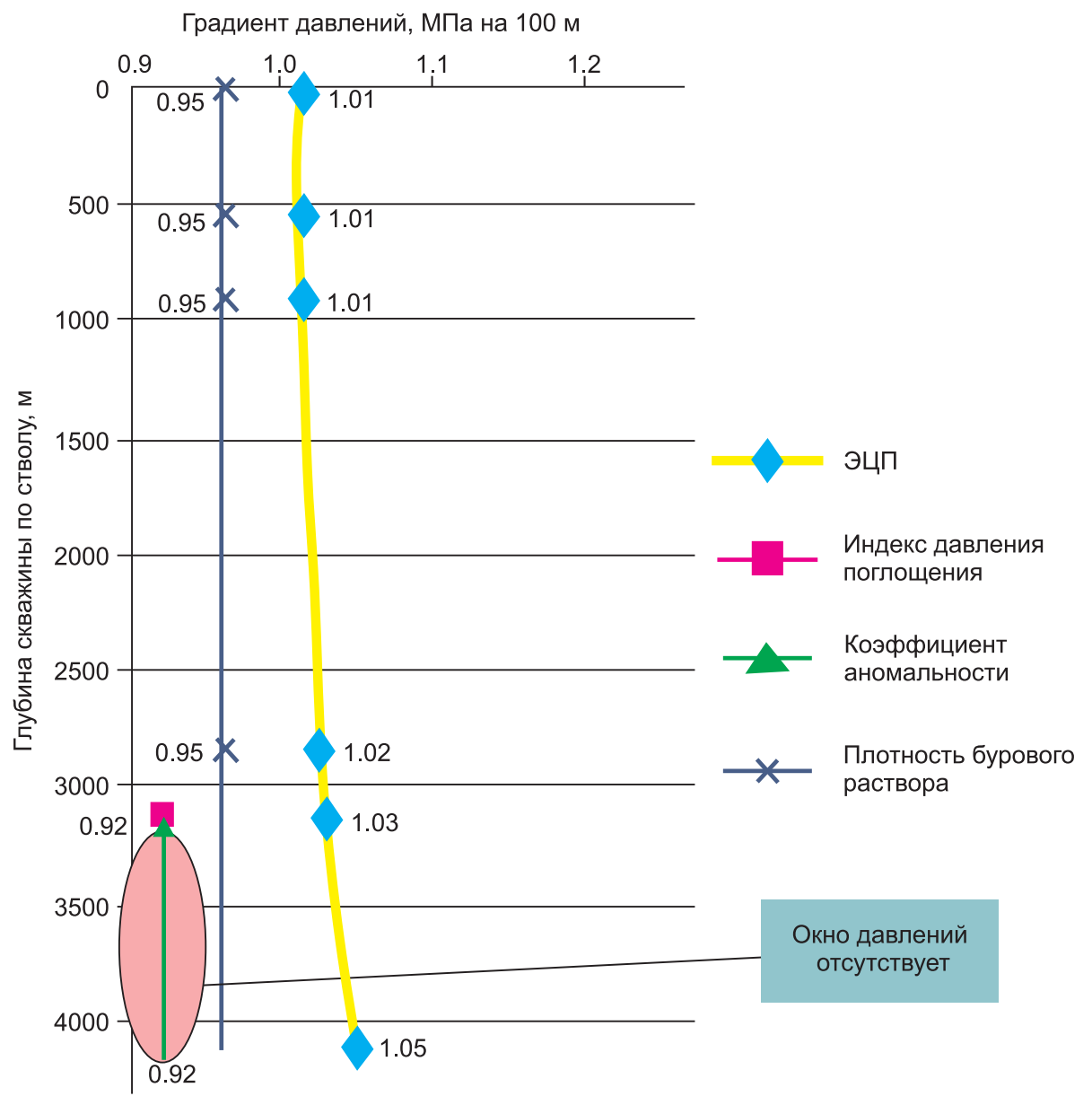

Рис. 3. График совмещенных давлений в интервале горизонтального ствола (зона 3). Аномально проницаемый карбонатный кавернозно-трещинный коллектор с АНПД. Вскрыты три зоны супертрещин. Все трещины открыты [Sverkunov et al., 2016b].

Fig. 3. Combined graph showing pressures in the interval of the horizontal well section (Zones 3). Anomalously permeable carbonate cavernous-fractured reservoir with abnormally low reservoir pressure. Three zones of supercracks are penetrated. All cracks are open [Sverkunov et al., 2016b].

(то есть в проектных сроках и решениях) первичного вскрытия бурением ГС. Эффекты одновременного поглощения и проявления в трещинных АНПД-системах не только изучены, они реально ограничивают на практике максимально достижимую длину ГС [Vakhromeev et al., 2015, 2017; Sverkunov et al., 2017].

Одним из важных итогов представленных исследований явилась разработка авторами технологии бурения трещинных ПР нефти и газа с АНПД пластовой УВ системы, проиллюстрированной в патенте РФ № 2598268 [Sverkunov et al., 2016a]. По своей сути эта технология представляет собой комбинированный вариант бурения продуктивного трещинного пласта «на репрессии» и «депрессии», что позволяет достичь «плавающего» баланса между периодическими поглощениями и проявлениями в бурящейся скважине [Vakhromeev et al., 2015, 2016, 2017; Sverkunov et al., 2016b].

\section{4. ОБСУЖДЕНИЕ РЕЗУЛЬТАТОВ ИССЛЕДОВАНИЙ}

\section{1. УСЛОВИЯ ДЕФОРМАЦИИ СЛОЖНЫХ КАВЕРНО-ТРЕЩИННЫХ КОЛЛЕКТОРОВ}

Снижение дебита скважины по нефти или другому флюиду обусловлено рядом причин, среди которых базовыми являются геомеханическая характеристика неустойчивого пласта-коллектора и реология пластовой УВ-системы при депрессии на пласт-коллектор [Borevsky, 1986; Belonin et al., 2005; Kashnikov et al., 2011]. К неустойчивым коллекторам следует отнести флюидонасыщенные стенки фильтрующих трещин в равновесном природном состоянии геомеханической (коллектор) и гидравлической (флюид) систем. Бурением это хрупкое равновесие нарушается [Vakhromeev et al., 2015, 2017; Sverkunov et al., 2016b; Polyakov et al., 1999], в ПЗП трещинная проницаемость меняется 

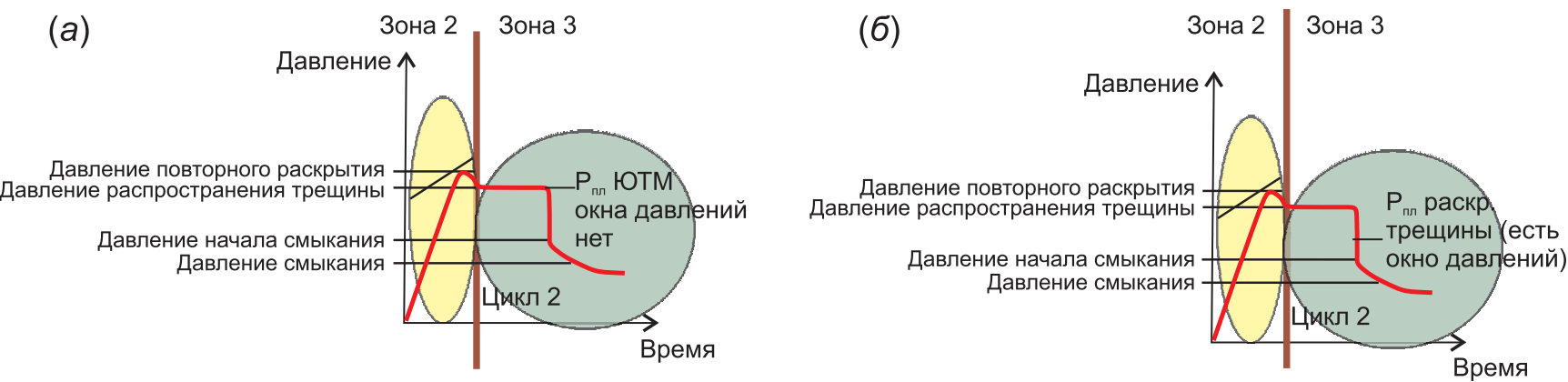

Рис. 4. Открытые фильтрующие трещины природного резервуара.

Fig. 4 . Open filtering cracks in a natural reservoir.

под воздействием импульсных гидравлических колебаний потока промывочной жидкости. В цикле испытания флюидонасыщенных пластов-коллекторов с трещинным и каверно-трещинным типом при деформации трещинной системы ПЗП (сжимание, «схлопывание» открытых проницаемых трещин) дебит фонтанирования флюида может снижаться до нуля. Таким образом, сегодня для конкретных объектов с трещинным типом коллектора в промысловых условиях отмечено снижение проницаемости и связанное с этим падение продуктивности и дебитов фонтанирования флюидов при освоении и испытании скважины, причем необратимое [Borevsky, 1986; Belonin et al., 2005; Kashnikov et al., 2011; Vakhromeev et al., 2015, 2017; Sverkunov et al., 2016b].

Не исключено, что эти же причины приводят также к изменению температурного (термобарического) режима, обуславливая фазовые переходы в пластовой многофазной системе (природные минеральные воды или промышленные концентрированные рассолы, углеводородная газоконденсатная или нефтегазовая пластовая система) [Zalivin, Vakhromeev, 2016].
Действительно, согласно исследованиям Г.Т. Овнатанова и др. [Ovnatanov, 1979; Borevsky, 1986; Belonin et al., 2005; Kashnikov et al., 2011], процесс снижения проницаемости призабойной зоны пласта в трещинных коллекторах при создании депрессии на продуктивный флюидонасыщенный пласт проходит необратимо. Этот вывод применительно к трещинным продуктивным объектам Лено-Тунгусской нефтегазоносной провинции имеет принципиальное значение. Он крайне важен, поскольку деформация (сжатие) проницаемых трещин носит системный характер, вызывая искажение (занижение) гидродинамических параметров [Belonin et al., 2005] и коэффициента продуктивности по флюиду в поисковых и разведочных скважинах.

Согласно работе [Borevsky, 1986], «...наиболее очевидной реакцией коллекторов на воздействие приложения внешних сил является их деформация. Обнаружение явления деформации коллекторов и заключенных в них жидкостей и газов послужило толчком к созданию теории упругого режима фильтрации, на которой базируются современные методы оценки эксплуатационных запасов флюи- (a)

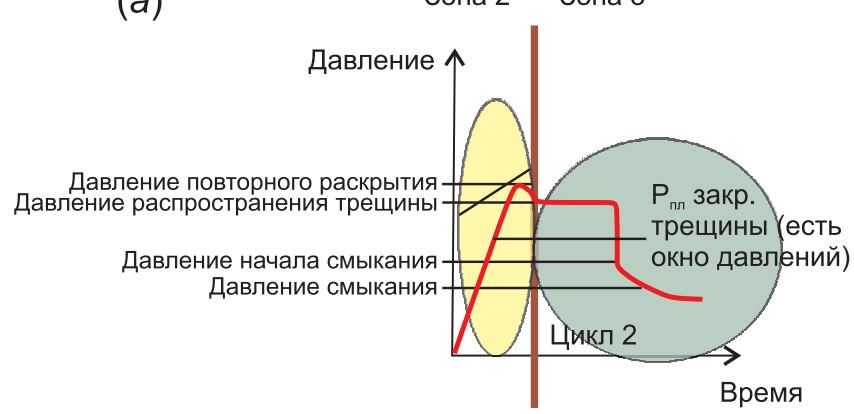

(б)

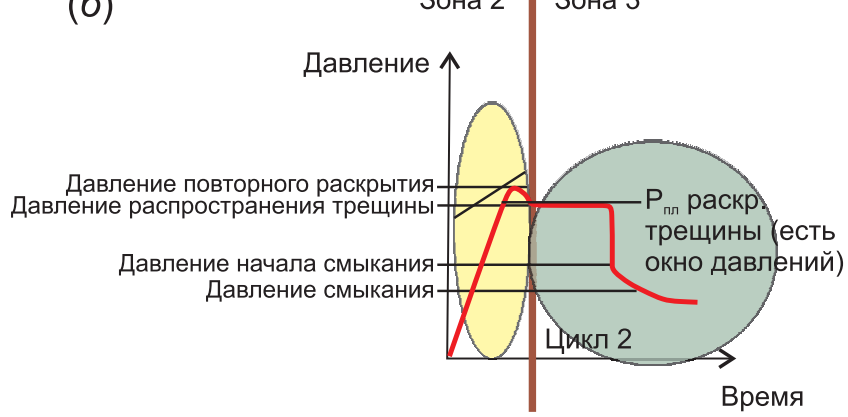

Рис. 5. Закрытые фильтрующие трещины природного резервуара.

Fig. 5. Closed filtering cracks in a natural reservoir. 
дов в напорных пластах». Деформация трещин в призабойной зоне скважины приводит к изменению перепада сечения фильтрационного потока от трещиноватого блока флюидонасыщенного коллектора в естественном, раскрытом состоянии к сжатию, деформации фильтрующих трещин. Таким образом, деформация, смыкание проницаемых трещин в призабойной зоне флюидонасыщенного пласта при изменении текущего забойного давления в область депрессии относительно значения пластового давления - нежелательное явление.

Поиск новых технологических подходов к сохранению проницаемости деформируемых трещинных коллекторов приводит нас к необходимости исследования закономерностей развития искусственной трещины ГРП по отношению к природным, естественным трещинам ПР. Ведь через воздействие ГРП сегодня решается комплекс задач кратного увеличения дебита пласта/ скважины по нефти и газу (флюиду), растет рентабельность разработки месторождения. В работе [Blanton, 1986] проведены эксперименты, показывающие, что гидравлическая трещина при искусственном ГРП является устойчивой и пересекает существующие природные трещины (ПТ) только в условиях большого соотношения между действующими напряжениями и большого угла между направлениями трещин. При средних и низких отношениях напряжений и малых углах между направлениями ПТ гидравлическая трещина раскрывает существующие в массиве ПТ и «разворачивает» поток флюида в направлении естественной трещиноватости. Согласно результатам численных расчетов [Barton et al., 1985], основанным на экспериментальных данных, низкая скорость потока жидкости приводит к тому, что трещина ГРП раскрывает существующие ПТ, в то время как высокая скорость потока и вязкость рабочего флюида приводят к тому, что трещина «не замечает» естественные трещины (ПТ), встречающиеся на пути ее развития.

В нашем же случае процесс неупругих деформаций наблюдается непосредственно в рабочих циклах бурения и испытания/освоения скважины, то есть при изменении гидравлической программы бурения, причем при минимальных колебаниях текущего забойного давления. Тогда процесс бурения скважин по деформируемому трещинами коллектору требует учета как в проектных решениях, так и в практике бурения именно в условиях минимальных градиентов динамического давления относительно градиента пластового давления флюидной системы ПР на этой глубине. Для цикла первичного вскрытия бурением нефтяного трещинного пласта это имеет особое значение, поскольку можно подобрать гидравлические условия щадящего вскрытия бурением природной трещиной си- стемы, при которых перепад давления на пластовую (флюидную) систему минимален или отсутствует.

Очевидно, что геолого-техническое, геологотехнологическое решение задачи разведки и разработки месторождений и залежей жидких и газообразных полезных ископаемых (нефти, газа, промышленных литиеносных рассолов, минеральных и термальных вод) лежит исключительно в разработке подхода к закреплению природных трещинных фильтрационных систем в области наиболее «жесткого» влияния перепада давлений (воронка депрессии). Такой областью является призабойная зона скважины - стенки скважины играют роль концентратов напряжений, а область наиболее значимого [Karev, 2010] влияния деформаций трещин оценивается радиусом около 4 м [Malyshev, 2009].

В то же время подчеркнем, что перепад давления в ПЗП (и в воронке депрессии/репрессии), где трещинный коллектор деформируется, это, по сути, переход от нерентабельной скважины к рентабельной в геолого-экономическом аспекте. Другими словами, это «узкое» место, или ключевая область, на стыке нефтяной геологии, гидрогеологии, бурения и разработки месторождений УВ или промышленных рассолов. Находя приемлемое научнотехническое решение и алгоритмы его внедрения в практику бурового цикла по деформируемым пластам-коллекторам на этапе ГРР, мы решаем вопрос сохранения естественной или улучшенной проницаемости ПЗП в области перепада давлений, которые приводят к деформации, тем самым меняя область некачественной (искаженной) кривой продуктивности [Belonin et al., 2005], кривой восстановления давления (КВД) на область качественных результатов в цикле ГДИ, но главное - возвращая в зону рентабельности значительные запасы месторождений нефти и газа [Kashnikov et al., 2011]. Такие решения разработаны авторами, экспериментально проверены в практике разведочного и эксплуатационного бурения глубоких скважин и защищены патентами РФ [Vakhromeev et al., 2015, 2016, 2017; Sverkunov et al., 2016a, 2016b, 2017]. При этом авторами предлагается комплекс технологических решений, позволяющих расширить диапазон величин допустимой депрессии на трещинный пласт.

\section{2. ИСКУССТВЕННОЕ ОПЕРЕЖАЮЩЕЕ ЗАКРЕПЛЕНИЕ ЕСТЕСТВЕННЫХ ТРЕЩИН В ПЕРВИЧНОМ ВСКРЫТИИ (ЛОГИЧНЫЙ ГЕОЛОГО-ТЕХНОЛОГИЧЕСКИЙ ВЫХОД)}

Сложность разработки каверно-трещинных карбонатных коллекторов природных резервуаров заключается, таким образом, в ухудшении фильтра- 
ционных свойств трещинного коллектора вследствие изменения трещинной проницаемости (деформации) за счет создания больших депрессий и неизбежного падения пластового давления в процессе эксплуатации залежи. Считается, что поддержание пластового давления в цикле эксплуатации нефтегазового или гидроминерального месторождения на уровне начальных (природных) значений сегодня является практически невыполнимой задачей. [Borevsky, 1986; Belonin et al., 2005; Lucia, 2007; van Golf-Racht, 1982]. Снижение пластового давления может идти различными темпами, и уже в первые месяцы - годы добычи пластовое давление может снизиться на несколько процентов. Этого снижения достаточно для начала смыкания трещин в продуктивном пласте, что доказано экспериментально [Belonin et al., 2005; Kashnikov et al., 2011]. Показано, что значительная величина депрессии, создаваемая в процессе эксплуатации залежи, оказывает отрицательное воздействие на фильтрационные свойства трещинного карбонатного коллектора, тем самым снижая продуктивность добывающих скважин по нефти, что в целом для месторождения может достигать 27 \%. Также деформация фильтрующих трещин в цикле очистки существенно искажает данные гидродинамических исследований скважины, коэффициент продуктивности и т.д.

При испытании (разведочные скважины) и освоении (эксплуатационные скважины и добыча) скважин величина депрессии на пласт должна находиться в жестких пределах с учетом конкретных горно-геологических условий [Borevsky, 1986; Belonin et al., 2005; Kashnikov et al., 2011]. Однако этот вывод прямо противоречит сложившейся практике эксплуатации месторождения УВ, где депрессии максимальны.

Другими словами, для трещинной фильтрационной системы, являющейся превалирующим типом емкостного и транзитного пространства природного карбонатного пласта-коллектора, необходимо разработать методологию испытания и освоения скважины, которая сохранит проницаемость трещинной системы в области призабойной зоны при воздействии сжимающих напряжений (массива горных пород), возрастающих при формировании воронки депрессии, в первую очередь в призабойной зоне пласта-коллектора при росте депрессии $(\Delta \mathrm{P})$ выше критических значений, что не позволит естественным проницаемым трещинам сомкнуться. Такой областью является призабойная зона в радиусе первых метров вокруг ствола скважины, вскрывшей трещинный пласт-коллектор.

Искомым решением может стать раскрытие естественных фильтрующих трещин с последующим их закреплением доступным проппантом (по аналогии с проведением процесса гидроразрыва пласта только с уже раскрытыми естественными трещинами) [Vakhromeev et al., 2016; Ivanishin et al., 2018].

Сам подход гидравлического воздействия на ПЗП в трещинном ПР может реализовываться в области не просто достижимых, а обычных по величине значений репрессии, обычных для бурения скважин нефтяного ряда. При этом последующее снижение величины текущего Рзаб приводит к закреплению проппантом просвета фильтрующих природных трещин (ПТ). В случае поглощения в ПТ в ПЗП, закрепленные таким образом природные трещины кольматируются на основе известных подходов [Polyakov et al., 1999]. Однако в последующем в циклах очистки трещинного пласта и его гидродинамических исследований и испытаний созданием депрессии смыканию трещин ПЗП препятствует ранее размещенный проппант. В то же время падение давления в призабойной зоне пласта ведет к закреплению проппанта.

Рассматриваемое технологическое решение может быть реализовано как в цикле первичного вскрытия бурением [Vakhromeev et al., 2016] горизонтального ствола в трещинном типе нефтегазонасыщенного карбонатного коллектора в условиях аномально низких пластовых давлений, так и в процессе освоения/испытания скважин [Ivanishin et al., 2018] в цикле геологоразведочных работ.

Процесс «закрепления» природных трещин становится возможным без проведения гидроразрыва в связи со специфическими особенностями фильтрационной системы трещинного карбонатного коллектора. Раскрытость естественных трещин может достигать от мДарси до единиц и нередко десятков Дарси. Основную роль в будущей продуктивности скважины играет именно вскрытие таких естественных высокопроницаемых трещиноватых зон. Первичное вскрытие бурением таких трещиноватых зон всегда характеризуется поглощением бурового раствора и увеличением интенсивности поглощения, что является индикатором для начала проведения работ по закреплению естественных трещин [Vakhromeev et al., 2016, 2017; Sverkunov et al., 2016b].

Здесь необходимо учитывать тот факт, что смыкание трещины в естественных условиях будет происходить только при снижении пластового давления ( $\mathrm{P}_{\text {пл }}$ конечное $<\mathrm{P}_{\text {пл }}$ начальное;

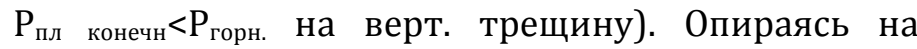
исследования [Malyshev, 2009], достичь эффекта закрепления проппанта в трещине можно только при условии, если во время закачки жидкости ГРП естественная трещина будет дополнительно раскрыта за счет увеличенного расхода закачки и соответственно большего давления на устье сква- 
жины. Разница давлений на устье скважины при низкой и высокой скорости закачки жидкости в скважину и будет индикатором того, что трещина расширилась относительно своего первоначального состояния.

\section{5. ЗАКЛЮЧЕНИЕ}

Важнейшее значение для разведки и разработки залежей нефти, газа и промышленных рассолов в трещинных резервуарах имеет соотношение давления флюида и давления на стенки трещины.

Давление смыкания [Kontorovich, 2004; Kashnikov et al., 2011; Doroginitskaya et al., 2016] для вертикальных трещин - это горизонтальная составляющая эффективного напряжения. Так, по данным бурения скважин с горизонтальным окончанием в рифее на одном из месторождений углеводородов юга Сибирской платформы, давление на стенки трещин ниже пластового, т.е. ниже 21.4 МПа, что составляет $1 / 3$ от вертикального горного [Sverkunov et al., 2016b].

Очевидно, что давление смыкания трещин ( $\left.\mathrm{P}_{\mathrm{CM}}\right)$ и пластовое давление (Р системы могут соотноситься как $\mathrm{P}_{\text {пл }}$ больше, меньше либо равно $\mathrm{P}_{\mathrm{cm}}$ (см. рис. 4,5 ). Это зависимость для естественных проницаемых трещин ПР. Обычно $\mathrm{P}_{\mathrm{CM}}$ рассматривается независимо от $\mathrm{P}_{п}$ как параметра вмещаемой флюидной системы. Тогда $\mathrm{P}_{\mathrm{cm}}$ - это доля от вертикального горного давления и составляющая его эффективного давления, которое показывает момент возникновения неупругих деформаций трещинного коллектора в процессе бурения. В качестве примера можно привести скважину Чайкинскую 367 [Doroginitskaya et al.,

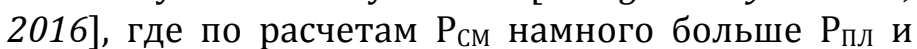
депрессия при очистке призабойной части пласта скважины не передается по трещинной системе, так как она закрыта. По данным [Vakhromeev et al., 2015], для трещинных коллекторов кембрия, вмещающих флюидную систему рассолов, процесс неупругих деформаций пласта коллектора трещинного типа происходит при отборе значительного объема пластового флюида, что приводит к резкому падению проницаемости ПЗП. После проведения соляно-кислотных обработок проницаемость восстановилась. В то же время нет убедительных доказательств необратимости сокращения пустотного емкостного пространства ПР, вскрытого скважинами Знаменскими 3А, 3Р, сформулированных в «Отчете по подсчету запасов». Модель необратимого сокращения пустотного пространства трещинного резервуара детально расписана Л.В. Боревским [Borevsky, 1986] и реализуется по механизму неупругих деформаций проницаемых трещин, при- чем процесс доказан как в области репрессий, так и в области депрессий [Vakhromeev et al., 2017, 2018; Borevsky, 1986; Belonin et al., 2005; Kashnikov et al., 2011].

Важнейшим научно-практическими выводом, на наш взгляд, является наблюдаемый в цикле первичного вскрытия бурением факт спонтанного закрепления фильтрующих трещин ПЗП технологическим шламом окремненных (до $80 \% \mathrm{SiO}_{2}$ ) доломитов, который при углублении скважины непрерывно поступает по затрубному пространству между бурильными трубами и стенками открытого ствола скважины. Системное явление, которое наблюдается в бурении ГС, - это уход шлама в трещины под гидравлическим импульсным волновым воздействием [Polyakov et al., 1999] потока бурового раствора. Именно на основе исследований этого явления авторами предложено инновационное решение проблемы опережающего закрепления естественных фильтрующих трещин [Vakhromeev et al., 2016; Ivanishin et al., 2018].

Таким образом, при вскрытии забоя бурением в деформированных трещинных карбонатных коллекторах имеют место импульсное раскрытие естественных трещин и поступление шлама в трещины и закрепление этих трещин разнофракционным шламом в момент максимального раскрытия.

Описанный механизм имеет как отрицательный, так и положительный эффект [Vakhromeev et al., 2015] [отрицательный - в осложнениях бурового цикла - формируются условия для устойчивого поглощения БР в приоткрытую систему естественных фильтрующих трещин природного резервуара на минимальных градиентах фильтрации). С ростом длины ГС эти градиенты растут, что приводит к увеличению интенсивности поглощения, а значит и к остановке углубления ствола [Vakhromeev et al., 2015; Siraev et al., 2013; Sverkunov et al., 2016b]. Этот процесс - бурение в условиях частичного поглощения и оценка границы рентабельности по продуктивному пласту - реализован в практике первичного вскрытия трещинных коллекторов [Vakhromeev et al., 2015, 2017]. С момента, когда интенсивность ухода БР в пласт превышает определенную величину (расхода), начинается цикл борьбы с поглощением: закачка вязкоупругих систем с кольматирующими составами и т.д.

Однако следует признать, что «попутное» закрепление трещин шламом при углублении ГС в условиях их искусственного приоткрывания гидравлическими импульсами потока БР - это крайне важный положительный процесс, прямо влияющий на эффективность последующей разработки углеводородного или гидроминерального месторождения. Эффект закрепления трещин стабилизирует коэффициент продуктивности скважины 
(нефть, газоконденсатная смесь, промышленные воды), поэтому обоснован технологический переход от спонтанного, неуправляемого закрепления трещин в цикле первичного вскрытия к запланированному, спроектированному [Vakhromeev et al., 2016; Ivanishin et al., 2018]. В этом случае могут быть экспериментально подобраны диаметры частиц проппанта, режимы закачки, перепад давлений, который способен удержать закачиваемый проппант при создании воронки депрессии. Рекомендуемая технология близка к технологиям проведения ГРП и требует дальнейших эксплуатационных исследований. Как следует из ранее выполненных исследований [Malyshev, 2009], закрепление эффективно непосредственно в призабойной зоне пласта.

На этапе геологоразведочных работ при планировании любых воздействий на продуктивный пласт, в т.ч. очистки ПЗП, исходят из того, что фильтрационная система постоянна [Borevsky, 1986; Belonin et al., 2005; Lucia, 2007; van Golf-Racht, 1982]. Если проницаемость ПЗП переменна, то это ведет к искажению базовых расчетных фильтрационных параметров пласта. При этом важно понимать, что искажения начинаются с процесса очистки продуктивного пласта. Тогда собственно результаты гидродинамических исследований продуктивного пласта также будут искажены.

Основной рекомендацией при разработке месторождений является рассмотрение природнотехнической системы на основе комплексного анализа ее составных частей [Polyakov et al., 1999; Zalivin, Vakhromeev, 2016]. В данном исследовании авторы постарались показать, что каждая часть системы вносит непосредственный вклад в общий комплекс. Так, на основе моделирования горногеологических условий одного из месторождений юга Сибирской платформы выданы рекомендации по первичному вскрытию бурением продуктивного пласта с соблюдением баланса забойного и пластового давления. Баланс достигается путем комбинирования текущего забойного давления в область репрессии и депрессии [Vakhromeev et al., 2015, $2017]$.

\section{6. ЛИТЕРАTУРA / REFERENCES}

Barton N., Bandis S., Bakhtar K., 1985. Strength, deformation and conductivity coupling of rock joints. International Journal of Rock Mechanics and Mining Sciences \& Geomechanics Abstracts 22 (3), 121-140. https://doi.org/ 10.1016/0148-9062(85)93227-9.

Belonin M.D., Slavin VI, Chilingar D.V., 2005. Abnormally High Reservoir Pressures. Origin, Forecast, Problems of Development of Hydrocarbon Deposits. Nedra, Saint Petersburg, 324 p. (in Russian) [Белонин М.Д., Славин В.И., Чилингар Д.В. Аномально высокие пластовые давления. Происхождение, прогноз, проблемы освоения залежей углеводородов. СПб.: Недра, 2005. 324 c.].

Blanton T.L., 1986. Propagation of hydraulically and dynamically induced fractures in naturally fractured reservoirs. In: SPE Unconventional Gas Technology Symposium (18-21 May, Louisville, Kentucky). SPE-15261-MS. https:// doi.org/10.2118/15261-MS.

Borevsky L.V., 1986. Analysis of the effect of physical deformations of reservoirs on the valuation of operational groundwater reserves in deep aquifers. In: S.S. Bondarenko, G.S. Vartanyan (Eds.), Methods of studying and estimating the resources of deep underground waters. Nedra, Moscow, p. 374-394 (in Russian) [Боревский Л.В. Анализ влияния физических деформаций коллекторов на оценку эксплуатационных запасов подземных вод в глубоких водоносных горизонтах // Методы изучения и оценка ресурсов глубоких подземных вод / Ред. С.С. Бондаренко, Г.С. Вартанян. М.: Недра, 1986. С. 374-394].

Dobrynin V.M., 1970. Deformations and Changes in the Physical Properties of Oil and Gas Collectors. Nedra, Moscow, 239 p. (in Russian) [Добрынин В.M. Деформации и изменения физических свойств коллекторов нефти и газа. М.: Недра, 1970. 239 с.].

Doroginitskaya L.M., Shiganova O.V., Stompelev I.E., 2016. Identification of producible reservoir rocks in the VendianCambrian of the Siberian Platform. A case study from the Chaykinskaya-367 parametric well. Geology and Mineral Resources of Siberia (2), 50-64 (in Russian) [Дорогиницкая Л.М., Шиганова О.В., Стомпелев И.Е. Выделение приточных пород-коллекторов в венд-кембрийских отложениях Сибирской платформы (на примере параметрической Чайкинской скв. 367) // Геология и минерально-сырьевые ресурсы Сибири. 2016. № 2. С. 50-64]. https://doi.org/10.20403/2078-0575-2016-2-50-64.

Ivanishin V.M., Vakhromeev A.G., Sverkunov S.A., Siraev R.U., Gorlov I.V., Lankin Yu.V., 2018. Patent № 2657052, June 8, 2018. Method for testing and development of a fluid-saturated reservoir of a fractured type (variants) (in Russian) [Иванишин В.М., Вахромеев А.Г., Сверкунов С.А., Сираев Р.У., Горлов И.В., Ланкин Ю.В. Патент №2657052 от 08.06.2018г. Способ испытания и освоения флюидонасыщенного пласта-коллектора трещинного типа (варианты). Заявка № 2017114085 (024647) от 21.04.2017].

Karev V.I., 2010. Influence of the Stress-Strain State of Rocks on the Filtration Process and Well Production. PhD Brief Thesis (Doctor of Technical Sciences). Institute of Problems of Mechanical Engineering of RAS, Saint Petersburg, 33 p. (in Russian) [Карев В.И. Влияние напряженно-деформированного состояния горных пород на филь- 
трационный процесс и дебит скважин: Автореф. дис. ... докт. техн. наук. СПб.: Институт проблем машиноведения РАН, 2010. 33 с.].

Kashnikov Yu.A., Gladyshev S.V., Razyapov R.K., Kontorovich A.A., Krasilnikova N.B., 2011. Hydrodynamic modeling of the prime development site of the Yurubcheno-Tokhomskoye field taking into account the geomechanical effect of cracks closing. Development and Operation of Oil Fields (4), 104-107 (in Russian) [Кашников Ю.А., Гладышев С.В., Разяпов Р.К., Конторович А.А., Красильникова Н.Б. Гидродинамическое моделирование первоочередного участка разработки Юрубчено-Тохомского месторождения с учетом геомеханического эффекта смыкания трещин // Разработка и эксплуатация нефтяных месторождений. 2011. № 4. С. 104-107].

Kharakhinov V.V., Shlenkin S.I., 2011. Oil and Gas Content of the Precambrian Strata of Eastern Siberia on the Example of the Kuyumbinsko-Yurubcheno-Tokhomsky Area of Oil and Gas Accumulation. Nauchny Mir, Moscow, 420 p. (in Russian) [Харахинов В.В., Шленкин С.И. Нефтегазоносность докембрийских толщ Восточной Сибири на примере Куюмбинско-Юрубчено-Тохомского ареала нефтегазонакопления. М.: Научный мир, 2011. 420 с.].

Kharakhinov V.V., Shlenkin S.I., Zereninov V.A., Kashirin H.V., Koulishkina O.N., Masyukov A.V., Masyukov V.V., Rud O.V., Berin M.V., 2012. New approaches to geological modeling of fractured reservoirs in East Siberia. Neftyanoye Khozyaystvo (Oil Industry) (11), 93-97 (in Russian) [Харахинов В.В., Шлёнкин С.И., Зеренинов В.А., Каширин Г.В., Кулишкина О.Н., Масюков А.В., Масюков В.В., Рудь О.В., Берин М.В. Новые подходы к созданию геологических моделей трещинных резервуаров в древних комплексах Восточной Сибири // Нефтяное хозяйство. 2012 . № 11. C. 93-97].

Kiselev V.M., Kinsfator A.R., Chashkov A.V., 2011. Anisotropy of permeability of fractured carbonate reservoirs. Scientific-Technical Bulletin of OJSC Rosneft (4), 10-14 (in Russian) [Киселев В.М., Кинсфатор А.Р., Чашков А.В. Анизотропия проницаемости трещиноватых карбонатных коллекторов // Научно-технический вестник OAO «НК Роснефть». 2011. № 4. С. 10-14].

Kiselev V.M., Chashkov A.V., Kinsfator A.R., Antonenko A.A., 2012. Determination of the optimal direction of the wellbore in fractured carbonate reservoirs. Scientific-Technical Bulletin of OJSC Rosneft (29), 16-20 (in Russian) [Киселев В.M., Чашков А.В., Кинсфатор А.Р., Антоненко А.А. Определение оптимального направления ствола добывающей скважины в трещиноватых карбонатных коллекторах // Научно-технический вестник ОАО «НК Роснефть». 2012. № 29. С. 16-20].

Kontorovich A.A., 2004. Calculation of oil, gas and condensate reserves of the Yurubcheno-Tokhomskoye field (within the Yurubcheno-Tokhomsky licensed area). Vol. 1. CJSC "Krasnoyarskgeofizika", Krasnoyarsk, 210 p. (in Russian) [Конторович A.А. Подсчет запасов нефти, газа и конденсата Юрубчено-Тохомского месторождения (в пределах Юрубчено-Тохомского лицензионного участка). Красноярск: ЗАО «Красноярскгеофизика», 2004. Т. 1. 210 c.].

Kontorovich A.A., Kontorovich A.E., Krinin V.A., Kuznetsov L.L., Nakaryakov V.D., Sibgatullin V.G., Surkov V.S., Trofimuk A.A., 1988. Yurubcheno-Tokhomskaya gas and oil accumulation zone: An important object of concentration of regional exploration efforts in the Upper Proterozoic of the Lena-Tunguska oil and gas province. Geologiya i Geofizika (Soviet Geology and Geophysics) 29 (11), 45-55 (in Russian) [Конторович А.А., Конторович А.Э., Кринин В.А., Кузнецов Л.Л., Накаряков В.Д.,Сибгатуллин В.Г., Сурков В.С., Трофимук А.А. Юрубчено-Тохомская зона газонефтенакопления важный объект концентрации региональных поисково-разведочных работ в верхнем протерозое ЛеноТунгусской нефтегазоносной провинции // Геология и геофизика. 1998. Т. 29. № 11. С. 45-55].

Kutukova N.M., Birun E.M., Malakhov R.A., Afanasiev I.S., Postnikova O.V., Rakhmatullina A.S., 2012. The conceptual model of Riphean carbonate reservoir in Yurubcheno-Tokhoma field. Neftyanoye Khozyaystvo (Oil Industry) (11), 4-7 (in Russian) [Кутукова Н.М., Бирун Е.М., Малахов Р.А., Афанасьев И.С., Постникова О.В., Рахматуллина А.С. Концептуальная модель строения рифейского природного резервуара Юрубчено-Тохомского месторождения // Нефтяное хозяйство. 2012. № 11. С. 4-7].

Lucia F.J., 2007. Carbonate Reservoir Characterization. An Integrated Approach. Springer, Berlin, 336 р. [Русский перевод: Лусиа Ф.Дж. Построение геолого-гидродинамической модели карбонатного коллектора. Интегрированный подход. Москва - Ижевск: Ижевский институт компьютерных исследований, 2010. 384 с.].

Malyshev S.V., 2009. Development of Hydraulic Fracturing Technology in Gas Wells. PhD Brief Thesis (Candidate of Technical Sciences). Moscow, 19 p. (in Russian) [Малышев С.В. Разработка технологии гидроразрыва пласта в газовых скважинах: Автореф. дис. ... канд. техн. наук. М., 2009. 19 с.].

Migursky A.V., 1997. Disjunctive Tectonics and Oil and Gas Content of Platform Areas: the Example of the South of the Siberian Platform. PhD Brief Thesis (Doctor of Geology and Mineralogy). Novosibirsk, 40 p. (in Russian) [Muгypский А.В. Дизъюнктивная тектоника и нефтегазоносность платформенных областей: на примере юга Сибирской платформы: Автореф. дис. ... докт. геол.-мин. наук. Новосибирск, 1997. 40 с.].

Migursky A.V., Starosel'tsev V.S., Melnikov N.V. Ryabkova L.V., Sobolev P.N., Surnin A.I., Chernova L.S., 2010. Experience of studying the Chaykinsky uplift - a large object of oil exploration on the Siberian platform. Geology and Mineral Resources of Siberia (4), 14-25 (in Russian) [Мигурский А.В., Старосельцев В.С., Мельников Н.В. Рябкова Л.В., Соболев П.Н., Сурнин А.И., Чернова Л.С. Опыт изучения Чайкинского поднятия - крупного объекта нефтепоисковых работ на Сибирской платформе // Геология и минерально-сырьевые ресурсы Сибири. 2010. № 4. C. 14-25].

Nazarova L.A., Nazarov L.A., Epov M.I., El'tsov I.N., 2013. Evolution of geomechanical and electro-hydrodynamic fields in deep well drilling in rocks. Journal of Mining Science 49 (5), 704-714. https://doi.org/10.1134/S106273914 9050031. 
Ovnatanov G.T., 1979. Opening and Treatment of the Formation. Nedra, Moscow, 312 p. (in Russian) [Овнатанов Г.Т. Вскрытие и обработка пласта. М.: Недра, 1979. 312 с.].

Pinneker E.V., 1977. Problems of Regional Hydrogeology. Nauka, Moscow, 196 p. (in Russian) [Пиннекер Е.В. Проблемы региональной гидрогеологии. М.: Наука, 1977. 196 с.].

Polyakov V.N., Ishkaev R.K., Lukmanov R.R., 1999. Oil and Gas Well Completion Technology. TAU, Ufa, 408 p. (in Russian) [Поляков B.Н., Ишкаев Р.К., Лукманов Р.P. Технология заканчивания нефтяных и газовых скважин. Уфа: ТАУ, 1999. 408 с.].

Postnikova I.E., Postnikova O.V., Tikhomirova G.I., Fomicheva L.N., 2001. The karst model of the Riphean natural reservoir of the Yurubcheno-Tokhoma deposit. Geologiya Nefti i Gaza (Oil and Gas Geology) (3), 36-41 (in Russian) [Постникова И.Е., Постникова О.В., Тихомирова Г.И., Фомичева Л.Н. Карстовая модель рифейского природного резервуара Юрубчено-Тохомского месторождения // Геология нефти и газа. 2001. № 3. С. 36-41].

Seminsky K.Zh., 2003. Internal Structure of Continental Fault Zones. Tectonophysical Aspect. Novosibirsk, Siberian Branch of RAS Publishing House, Geo Branch, 244 p. (in Russian) [Семинский К.Ж. Внутренняя структура континентальных разломных зон. Тектонофизический аспект. Новосибирск: Изд-во СО РАН, филиал «Гео», 2003. 244 c.]

Seminsky K.Zh., Kozhevnikov N.O., Cheremnykh A.V., Pospeeva E.V., Bobrov A.A., Olenchenko V.V., Tugarina M.A., Potapov V.V., Zaripov R.M., Cheremnykh A.S., 2013. Interblock zones in the crust of the southern regions of East Siberia: tectonophysical interpretation of geological and geophysical data. Geodynamics \& Tectonophysics 4 (3), 203-278 (in Russian) [Семинский К.Ж., Кожевников Н.О., Черемных А.В., Поспеева Е.В., Бобров А.А., Оленченко В.В., Тугарина М.А., Потапов В.В., Зарипов P.М., Черемных А.C. Межблоковые зоны в земной коре юга Восточной Сибири: тектонофизическая интерпретация геолого-геофизических данных // Геодинамика и тектонофизика. 2013. T. 4. № 3. C. 203-278]. https://doi.org/10.5800/GT-2013-4-3-0099.

Siraev R.U., Sverkunov S.A., Danilova E.M., Sotnikov A.K., Vakhromeev A.G., 2013. Analysis of mining and geological conditions for drilling oil and gas prospecting wells at Danilovskaya Square, Nepsky Vault. Proceedings of Irkutsk State Technical University (12), 131-135 (in Russian) [Сираев Р.У., Сверкунов С.А., Данилова Е.М., Сотников А.К., Vakhromeev A.Г. Анализ горно-геологических условий бурения геологоразведочных скважин на нефть и газ на Даниловской площади, Непский свод // Вестник Иркутского государственного технического университета. 2013. № 12. С. 131-135].

Sverkunov S.A., Vakhromeev A.G., Siraev R.U., 2016a. Patent No. 2598268 of October 13, 2016. The method of primary opening of a complex cavernous-fractured carbonate oil-gas-saturated reservoir by a horizontal trunk of a large extent (in Russian) [Сверкунов С.А., Вахромеев А.Г., Сираев Р.У. Патент № 2598268 от 13.10.2016 г. Способ первичного вскрытия сложного кавернозно-трещинного карбонатного нефтегазонасыщенного пласта горизонтальным стволом большой протяженности].

Sverkunov S.A., Vakhromeev A.G., Siraev R.U., Danilova E.M., 2016b. Drilling of Wells with Completion by Horizontal Sections in Complex Mining and Geological Conditions (As Exemplified by the Natural Carbonate Reservoirs of the Riphean in the Baikit Petroliferous District). Publishing House of Irkutsk National Research Technical University, Irkutsk, 204 p. (in Russian) [Сверкунов С.А., Вахромеев А.Г., Сираев Р.У., Данилова Е.М. Бурение скважин с горизонтальным окончанием в сложных горно-геологических условиях (на примере природных карбонатных резервуаров рифея Байкитской НГО). Иркутск: Изд-во ИРНИТУ, 2016. 204 с.].

Sverkunov S.A., Vakhromeev A.G., Siraev R.U., 2017. Patent No. 2617820. The Russian Federation IPC E21B43/30. Method for determining the maximum length of a horizontal trunk in conditions of a cavernous cracked carbonate oil-gas-saturated reservoir with an abnormally low reservoir pressure. RU 2617820 C1; claimed 11/09/2015., publ. 27.04.2017, Bull. No. 12 (in Russian) [Сверкунов С.А, Вахромеев А.Г., Сираев Р.У. Патент № 2617820 Российская Федерация МПК Е21B43/30. Способ определения максимальной длины горизонтального ствола в условиях каверново-трещинного карбонатного нефтегазонасыщенного пласта с аномально низким пластовым давлением. RU 2617820 C1; заявл. 11.09.2015 г., опубл. 27.04.2017 г., Бюл. № 12].

Svintsitsky S.B., 2006. Prediction of Mining and Geological Conditions for Wells in Saline and Clay Sediments with Abnormally High Pressures of Fluids. PhD Thesis (Doctor of Geology and Mineralogy). Stavropol, 547 p. (in Russian) [Свинцицкий С.Б. Прогнозирование горно-геологических условий проводки скважин в соленосных и глинистых отложениях с аномально высокими давлениями флюидов: Дис. ... докт. геол.-мин. наук. Ставрополь, 2006. 547 с.].

Usachev P.M., 1986. Hydraulic Fracturing of the Reservoir. Nedra, Moscow, 165 p. (in Russian] [Усачев П.М. Гидравлический разрыв пласта. М.: Недра, 1986. 165 с.].

Vakhromeev A.G., Danilova E.M., Razyapov R.K., Ivanishin V.M., Siraev R.U., 2014. Anomalously-permeable fractured vein and karst vein carbonate reservoir in Riphean of the Yurubchen-Tokhoma petroleum field (by field-geological data of horizontal drilling). Geology and Mineral Resources of Siberia (4), 49-61 [Вахромеев А.Г., Данилова Е.М., Разяпов Р.К., Иванишин В.М., Сираев Р.У. Аномально-проницаемый трещинно-жильный и карстово-жильный карбонатный коллектор в рифее, Юрубчено-Тохомское НГКМ (по геолого-промысловым данным горизонтального бурения) // Геология и минерально-сырьевые ресурсы Сибири. 2014. № 4. С. 49-61].

Vakhromeev A.G., Razyapov R.K., Postnikova O.V., Kutukova N.M., Sverkunov S.A., Siraev R.U., 2015. Lithological and hydrodynamic factors controlling conditions of primary horizontal drilling and development of producing intervals of the riphean natural reservoir in the Yurubcheno-Tokhoma oil-gas-condensate field. Geology and Mineral 
Resources of Siberia (3), 68-82 [Вахромеев А.Г., Сверкунов С.А., Постникова О.В., Кутукова Н.М., Разяпов Р.К., Сираев Р.У. Литологические и гидродинамические факторы, определяющие условия первичного вскрытия и освоения продуктивных интервалов рифейского природного резервуара Юрубчено-Тохомского НГКМ по геолого-промысловым данным горизонтального бурения и отбора керна в наклонных стволах // Геология и минерально-сырьевые ресурсы Сибири. 2015. № 3. С. 68-82].

Vakhromeev A.G., Sverkunov S.A., Ivanishin V.M., Misyurkeeva N.V., Buddo I.V., 2018. Transient stressed states of the mountain massif of fluid-saturated carbonate reservoirs. In: EAGE. Saint Petersburg (April 2018) (in Russian) [Вахромеев А.Г., Сверкунов С.А., Иванишин В.М., Мисюркеева Н.В., Буддо И.В. Переходные напряженные состояния горного массива флюидонасыщенных карбонатных коллекторов // ЕАГЕ. Санкт-Петербург (апрель 2018)].

Vakhromeev A.G., Sverkunov S.A., Ivanishin V.M., Razyapov R.K., Danilova E.M., 2017. Geodynamic aspects in the study of complex mining and geological conditions for drilling into oil-and-gas reservoirs in the Riphean carbonate rocks: an overview of the problem as exemplified by the deposits in the Baikit petroliferous district. Geodynamics \& Tectonophysics 8 (4), 903-921 (in Russian) [Вахромеев А.Г., Сверкунов С.А., Иванишин В.М., Разяпов Р.К., Данилова Е.М. Геодинамические аспекты исследования сложных горно-геологических условий бурения древнейших карбонатных резервуаров нефти и газа рифея: обзор проблемы на примере месторождений Байкитской нефтегазоносной области // Геодинамика и тектонофизика. 2017. Т. 8. № 4. С. 903-921]. https://doi.org/ 10.5800/GT-2017-8-4-0323.

Vakhromeev A.G., Sverkunov S.A., Siraev R.U., Razyapov R.K., Sotnikov A.K., Chernokalov K.A., 2016. Patent No. 2602437. The Russian Federation IPC E21B21/00, E21B33/13, E21B43/02. The method for penetration into oil-saturated fractured carbonate strata by drilling the wells with horizontal sections in the conditions of anomalously low reservoir pressure rates. RU 2602437 C1; appl. 11.09.2015, publ. 20.11.2016, Bull. No. 32 (in Russian) [Вахромеев А.Г., Сверкунов С.А., Сираев Р.У., Разяпов Р.К., Сотников А.К., Чернокалов К.А. Патент № 2602437. Российская Федерация МПК Е21B21/00, E21B33/13, E21B43/02. Способ первичного вскрытия бурением горизонтального ствола в трещинном типе нефтегазонасыщенного карбонатного коллектора в условиях аномально низких пластовых давлений. RU 2602437 C1; заявл. 11.09.2015, опубл. 20.11.2016, Бюл. № 32].

van Golf-Racht T.D., 1982. Fundamentals of Fractured Reservoir Engineering. Elsevier, Amsterdam, 732 р. [Русский перевод: Голф-Рахт Т.Д. Основы нефтепромысловой геологии и разработки трещиноватых коллекторов. М.: Недра, 1986. 608 с.].

Zalivin V.G., Vakhromeev A.G., 2016. Emergency situations in drilling. Textbook. Irkutsk National Research Technical University Publishing House, Irkutsk, 500 p (in Russian) [Заливин В.Г., Вахромеев А.Г. Аварийные ситуации в бурении. Учебное пособие. Иркутск: Изд-во ИрНИТУ, 2016. 500 с.].

\section{Андрей Гелиевич Вахромеев}

докт. геол.-мин. наук, зав. лабораторией

Институт земной коры СО РАН

664033, Иркутск, ул. Лермонтова, 128, Россия

Иркутский филиал 000 «РН-Бурение»

664033, Иркутск, ул. Лермонтова, 257, Россия

Иркутский национальный исследовательский технический университет

664074, Иркутск, ул. Лермонтова, 83, Россия

\e-mail: VakhromeevAG@ifrnb.ru

Владимир Мирославович Иванишин директор

Иркутский филиал 000 «РН-Бурение»

664033 , Иркутск, ул. Лермонтова, 257, Россия

\section{Andrei G. Vakhromeev}

Doctor of Geology and Mineralogy, Head of Laboratory

Institute of the Earth's Crust, Siberian Branch of RAS

128 Lermontov street, Irkutsk 664033, Russia

Irkutsk Branch of LLC RN-Burenie

257 Lermontov street, Irkutsk 664033, Russia

Irkutsk National Research Technical University

83 Lermontov street, Irkutsk 664074, Russia

\section{Vladimir M. Ivanishin}

Director

Irkutsk Branch of LLC RN-Burenie

257 Lermontov street, Irkutsk 664033, Russia 
A.G. Vakhromeev et al.: Deep well as a facility for on-line hydraulic studies of the stress state...

\section{Сергей Александрович Сверкунов}

канд. геол.-мин. наук

Институт земной коры СО РАН

664033, Иркутск, ул. Лермонтова, 128, Россия

Иркутский филиал 000 «РН-Бурение»

664033, Иркутск, ул. Лермонтова, 257, офис 909, Россия

Иркутский национальный исследовательский

технический университет

664074, Иркутск, ул. Лермонтова, 83, Россия

Иркутский научный центр СО РАН

664033, Иркутск, ул. Лермонтова, 134, Россия

e-mail: dobro_75@mail.ru

\section{Владимир Николаевич Поляков}

докт. техн. наук, профессор

Институт нефтегазовых технологий и новых материалов Республики Башкортостан

450075, Уфа, пр. Октября, 129/3, Россия

e-mail: intnm@ya.ru

\section{Радий Киньябулатович Разяпов}

канд. геол.-мин. наук, главный геолог

000 «Соровскнефть»

625002, Тюмень, ул. Орджоникидзе, 5, Россия

e-mail: RazyapovRK@vsnk.ru

\section{Sergei A. Sverkunov}

Candidate of Geology and Mineralogy

Institute of the Earth's Crust, Siberian Branch of RAS

128 Lermontov street, Irkutsk 664033, Russia

Irkutsk Branch of LLC RN-Burenie

Office 909, 257 Lermontov street, Irkutsk 664033, Russia

Irkutsk National Research Technical University

83 Lermontov street, Irkutsk 664074, Russia

Irkutsk Scientific Center, Siberian Branch of RAS

134 Lermontov street, Irkutsk 664033, Russia

\section{Vladimir N. Polyakov}

Doctor of Technical Sciences, Professor

Institute of Oil and Gas Technologies and New Materials of the Republic of Bashkortostan

129/3 Oktyabr' ave., Ufa 450075, Russia

\section{Radiy K. Razyapov}

Candidate of Geology and Mineralogy, Chief Geologist

LLC Sorovskneft

5 Ordzhonikidze street, Tyumen 625002, Russia 